\title{
From Native Courts to People's Local Courts: The Politics of Ju- dicial Administration in Sudan
}

\author{
By Musa Adam Abdul-Jalil
}

\section{Introduction}

This paper ${ }^{1}$ deals with the development of customary law courts in the Sudan. An attempt is made to discuss the various factors that have influenced events at different stages of their history. Because the factors are mainly political in nature, I intend to use a social control perspective which is best suited for this type of exercise. In the summer of 1982 I spent one month doing fieldwork on customary law courts in northern Darfur (mainly Kutum and Kabkabiya). I also collected invaluable information from the Attorney General's Chambers and the Central Records Office in Khartoum.

Subsequently, I came to realise that the special features that characterized the development of customary courts in northern Darfur were produced by factors originating beyond the limits of the region. Indeed the same factors have influenced the development of customary courts in all of the Sudan. These factors have to do with the nature and function of centralized political agencies and interest groups. I then started to see the disadvantage of the traditional anthropological practice of limiting one's study to a convenient, artificially constructed ethnographic area. For had I followed my original plan, the scope of my analysis would have necessarily been narrow, consequently depriving me of the chance to see the development of social institutions in terms of their broader connections. I therefore decided to reverse my plans and look at the system nationwide.

The judicial system in Sudan is pluralistic both in terms of its organization and the content of ist laws. There are two major separate hierarchies of courts; the Sharia Division and the Civil Division. The former administers Islamic law as it relates to personal status (mainly family law). ${ }^{2}$ The second hierarchy is constituted mainly of Civil

1 A draft of this article was present at a conference on 'Law and Development in Contemporary Societies of the Middle East ' held during the spring of 1983 in Berkeley (USA). The Research Board of the Faculty of Economic and Social Studies, University of Khartoum provided the fund for collecting the data on which the article is based. The writing phase was assisted by a fellowship award from the Joint Committee on the Near and Middle East of the Social Science Research Council and the American Council of Learned Societies with funds provided by the United States Agency for International Development.

I thank Laura Nader, Elizabeth Colson and Smadar Levie for encouragement and comments on an earlier draft.

2 The Judiciary Acts of 1972 and 1973 abolished the separate hierarchy of Sharia Courts whereby they are now incorporated as a circuit of personal law within an integrated ordinary court system. The office of Grand Qadi, who used to lead the Sharia Courts, was abolished and the role is now played by a Supreme Court vice-president. The integration is only a formal one but they remain in essence as separate hierarchies. 
(ordinary) Courts that administer a basically Europeantype law, introduced by the British at the end of the last century and retained by various independent Sudanese governments with minor additions or adjustments. Attached to the civil hierarchy, at ist lower end, is a sub-system of customary courts with its own two-level hierarchy. ${ }^{3}$ Although formally a part of the Civil Division, the customary courts remain in essence a separate system if only for the reason that they administer customary law. Given the diversity of ethnic cultures in Sudan, it is not difficult to imagine the multiplicity within the sub-system. Despite their lower status within the judicial system as a whole, customary courts in Sudan handle more cases than the Sharia and ordinary courts put together. The Attorney General estimated the proportion of work handled by customary courts in 1975 to be in the vicinity of $70 \%$ of the volume of judicial work in Sudan. In fact they represent the major formal dispute management agent in rural areas. Since trained lawyers are in short supply in the country, this situation is likely to continue for a long time.

Courts have been traditionally considered as agents of dispute settlement or conflict resolution or, as I prefer to say, "dispute management". Courts, however, are also agents of government (see Shapiro, 1981). As such they have functions of social control, social engineering and administration. Because in practice these occur together I shall refer to them collectively as social control. In this paper I am not going to discuss dispute management but rather will look at the courts from a social control perspective. Since one of the many functions of the state is the control of people within a given territory, it is inevitable that courts (being part of the state apparatus) will be partially utilized for that purpose. But the state itself is not a unified power structure. It is rather a medium through which the interests of power groups are articulated. Writing about law and the distribution of power, Laura Nader and David Serber (1976) stated that national law is a mechanism and a process which can be used to legitimate and maintain power groups. I would argue that the legal system in Sudan is no exception.

Sudanese customary courts act as agents of centralized power (the state) to control the rural population. At the same time, the state itself is subject to political manipulation by various power groups such as political parties, professional groups and elites - traditional as well as educated. As a result, the courts have become tools of power politics. Controlling processes are no longer simple or unidirectional, for as the government wants to control the people some groups are interested in controlling the government all trying to utilize customary courts for their ends. As one scholar has pointed out, "Conquerors use courts as one of their many instruments for holding and controlling conquered territories. And more generally, governing authorities seek to maintain or increase their legitimacy through the courts". (Shapiro, 1981:22).

My purpose is therefore to trace the history of customary law courts in Sudan and examine the political interests that influenced the various developments that these courts

3 Before 1969 customary courts also had Sharia jurisdiction. A sharia advisor used to be attached to each court for this purpose. Appeals on personal law cases were then made to District Sharia Courts. 
witnessed during the last five decades. In doing so, I may appear as deliberately undermining genuine attempts at reforming the legal system. It is, however, my contention that reforms are better achieved when the phenomenon in question $-i$. e. the legal system - is understood. The fact that the various reforms have taken customary courts almost full circle illustrates the point that reformers have confused political interests with the public good. It is for this reason that, I believe, a sociological study of customary courts using a social control perspective is most needed.

\section{Colonial Historical Background}

The British administration was anxious to consolidate its position after the reoccupation of the Sudan in 1898. The burning issue at the time for the colonial administrators was the question of law and order. One of the alternatives they had was to introduce a variant of the policy of indirect Rule which was applied in other African territories. At first this was not made legally explicit. The first enactment in this direction came in 1922 when the Nomad Sheikhs Ordinance was passed. It dealt mainly with nomadic populations. However, in 1925 the Village Courts Ordinance was introduced to deal with sedentary populations. The Sheikhs Ordinance 1928 (which repealed the 1922 Ordinance) was meant to increase the powers of tribal leaders and improve their administrative performance. The Village Courts Ordinance was also amended in 1930 for the same purpose. One of the problems that colonial field administrators faced in their efforts to apply the policy of Indirect Rule was the fact that many Sudanese communities did not have centralized political institutions with strong figures to be entrusted with the task of administration. Consequently they had to create such figures in many communities. This was the case with many nomadic groups such as the Kababesh and Baggara.

The shift from Indirect Rule to what came to be called Indirect Administration resulted in the institutionalization of native administration in the early thirties. The Chief's Courts Ordinance 1931 was devised mainly for Southern Sudan. For the rest of the country, the Native Courts Ordinance 1932 marked the effective beginning of the new era. The 1928 and 1930 ordinances were repealed by the new ordinance. From the beginning the government was ready to allow the natives to apply their customs in settling disputes so long as these customs were acceptable to the British. Later it specified the conditions under which custom might be applied. Thus provision (a) of subsection (1) of section (9) regarding the law to be administered stated: The native law and custom prevailing in the area or in the tribe over which the court exercises its jurisdiction provided that such native law and custom is not contrary to justice, morality or order'. The interest of the government in controlling the population was further manifested in the limitations placed on the jurisdiction of these courts. The following provisions of subsection (1) of section (8) state . . that no native court shall have the power to (c) hear any case concerning the ownership of land except a claim for partition of land registered under the Land Settlement and Registration Ordinance 1925 and owned in undivided 
shares by co-heirs, ${ }^{4}$ or (d) to try any criminal case in which the accused is a government official.

The main concern of British administrators was therefore to use the elites, whom they either created or recognized as part of the system of government, to control their own fellow tribesmen. The limitations that they put on the exercise of their powers was meant to prevent the system from being used against the government. Thus, while native courts could punish citizens who failed to comply with rules set forth by officials, they were denied the authority to sanction the behaviour of government officials towards the public. The control was meant to operate in one direction only. This was far from the original theory of Indirect Rule specified by Lugard as Gaafar Bakheit has argued (1971). According to him the British also intended native administration to act as a shield against rebellious religious elements and the Egyptians with whom the administration of the country was shared.

The native Courts Ordinance then became the corner stone in the elaborate system of native administration that was subsequently developed. Tribal chiefs who were presidents of native courts also became administrative agents, collecting taxes and applying local government regulations. The multiplicity of roles they played is well expressed by the following statement of Lord Hailey (quoted by Bakheit) who defined the new system of native administration to mean

a procedure by which a colonial government whose European establishment is necessarily restricted in numbers, has provided itself with administrative machinery required for certain definite purposes of which the most important was the supervision of the tribal communities, the maintenance of law and order, the assessment of taxes, the provision of local government services, and the establishment of judicial tribunals (Bakheit, 1971).

The wide range of authority which the native agents enjoyed was a result of the expedient nature of the British policy in Sudan. This later constituted the main source of criticism against the system. Ironically, it is this wider reference of authority that enabled native administration to function effectively. The chiefs used their judicial powers to support their decisions as administrators. They were therefore able to sanction the behavior of their political opponents who could be brought in front of a native court for any violation ranging from cutting a tree to refusal of paying taxes (which the chief himself assessed). Native administration with its twin institution of native courts continued to function as the backbone of local government in rural Sudan even after the country became independent in 1956 under the first civilian government which administered the country for two years before it was overthrown by a military junta in 1958. Nevertheless, immediately after independence opposition against native administration became strong. There were two main foci of opposition:

First, dissenting elements within tribal groups who were motivated by a desire for 
autonomy within their local communities either because of competition between subtribes and clans or the misconduct and harsh treatment by their chiefs.

Second, liberal elements of the educated elite who had been involved in the struggle for independence. They were anxious to see their country develop into a modern state governed by the rule of law and granting civil liberties to all its citizens. For them, native administrators were exploiters of their fellow citizens. Exploitation was largely facilitated through the monopoly of dues over unregistered land, especially in riverine areas where chiefs were able to make fortunes for themselves. In many areas in the country this criticism was less applicable because of the nature of property development (e. $g$. Western Sudan).

Although the military regime which came to power in 1958 did not respond to these criticisms, the opposition voiced during that period planted the seeds for major developments in the stages that followed.

\section{The October 1964 uprising and the Move for Liquidation of Native Courts}

It was not until the popular uprising of 21 st October 1964 - which resulted in the overthrow of the military junta - that the opposition to native administration gained full force. Radical leftist elements now spearheaded the opposition forces. The first move was initiated from within the government itself. The Minister for Cabinet Affairs, who was also the Secretary of the Sudan Federation of Trade Unions and the representative of the Labour Movement in the Revolutionary Front of 21 st October, submitted a memorandum to the cabinett calling for the liquidation of native administration on the grounds that it was inconsistent with the wishes of the Sudanese people and out of line with the spirit of the revolution. He envisaged elected local government councils to carry out the functions of native administration. The minister went on to suggest the adoption by the government of the following measures as a matter of urgency: ${ }^{5}$

(a) The suspension of native administration in northern Sudan and the distribution of its functions among various specialized agencies.

(b) The repeal of the Chief's Courts and Native Courts Ordinances.

(c) The judicial powers of nazirs, omdas and shaikhs should be withdrawn from them and vested in the Judiciary.

(d) The consolidation and increase of local government police to fill the vacuum created by dismissal of nazirs, omdas and shaikhs.

(e) The increase of local government staff so that they could discharge the responsibilities which members of the native administration used to perform.

(f) The formation of purge committees to punish corrupt native administration personal.

(g) As a demonstration of the Government's serious approach to the matter, native administration should immediately be liquidated in the Blue Nile, Northern, Kass-

5 The contents of the memorandum have been translated and summarized by Bakheit (1971). 
ala, Khartoum, Kordofan and Darfur provinces and a commission formed to investigate the necessary plans for liquidating native administration in the southern provinces (Bakheit, 1971).

The above quotation actually summarizes not only the attitude of the left, but that of the liberal educated elite in general towards native administration. Although the tide seemed strong, subsequent developments reflected the complex political nature of the liquidation issue.

The leftists, who lead the liquidation movement, saw it as a revolutionary step directed towards the formation of a new administrative set-up that would pave the way for a new social order. The restructuring of social relations could only be achieved after the removal of the tribal elites who were seen as agents of imperialism. However, behind the revolutionary rhetoric lay reasons of pragmatic politics. It was well known that the two large traditional national parties (The Umma Party and the National Unionist Party) had sought the cooperation of various tribal leaders in their campaign for elections to the first parliament after independence. Candidates were able to utilize alliances with tribal chiefs and leaders to win the votes of entire groups. This gave chiefs friends in the upper echelons of government. In other words, such alliances served mutual interests for the parties concerned.

By contrast, the leftist elements did not have such connections with tribal elites. They had nothing to lose from the liquidation of native administration. More positively, they were bound to benefit politically from such a decision since it was going to undermine the influence of the traditional nationalistic parties. Accordingly one can argue that the leftists wanted to pull the rug from under their rivals by utilizing the revolutionary zeal of the October uprising.

The second group that called for liquidation were the Islamicists, the ideological opposite of the left. They also wanted access to the rural voters but found the alliance of nationalistic parties with the tribal elites a serious obstacle. Apart from pragmatic politics, the Islamicists, as radical fundamentalists, were ideologically interested in communicating with the rural Muslim populace. They had been thwarted by the two traditional parties who monopolized religious organization in rural Sudan through the maintenance of a close relationship between the parties and the leadership of the two main religious sects. It is clear why supporting the liquidation of native administration could be rewarding for the Islamic fundamentalists. It remains to be mentioned that both leftists and Islamicists were educated elites based in the few large urban centers in the country.

A third group was interested in supporting the liquidation movement for yet a different reason. The judiciary, interested in the development of a unified legal system, raised the banner of the separation of judicial powers even bevore the October uprising. They intended to separate the judicial powers vested in the native administration by two means: (a) appointment of court presidents who did not have the administrative capacity of chiefs and (b) the supervision of native courts by the judiciary and not by the local government ministry. Such measures would undoubtedly have rendered the chiefs ineffi- 
cient and toothless as native administrators since they would lack the judicial power that enabled them to sanction and control people.

The anti-liquidation forces were quick to respond, though they were careful not to present their argument in terms of opposition to the principle of liquidation. They focussed instead on the pragmatic side of the issue. The cabinet responded to the liquidation memorandum by adopting it in principle but formed a commission which was to study and report on how to liquidate, to present alternative plans and work out the financial costs. This slowed the speed of events which later proved to be of great service to the anti-liquidation forces.

The tribal leaders, the first of these forces, quickly rose to the challenge by forming the first Tribal Leaders Association in Sudan. They adopted a twofold strategy. They started by sending a letter to the Prime Minister in which they emphasized their roles of tax collecting, peace keeping and above all the creation of stability which the government badly needed in order to embark on any program for developing the country. They also adopted the strategy of relaxing their tax collecting activities and being lenient on their people.

By this time, the second group of anti-liquidation forces - which consisted of local government administrators and police officers - began to realize the effects the liquidation of native administration might have on administration in general and tax collection and security in particular. It was pointed out to the leading officials in the Ministries of the Interior and of Local Government that the separation of native courts from native administration would undermine the maintenance of security in the rural areas. While formally recognizing the legitimacy of the liquidation call they tried to emphasize the effect on field administration if the policy was to be implemented immediately.

The political parties which benefited form the alliance with native administrators were careful not to show open opposition to the liquidation movement as a matter of principle for such a move would have affected their credibility in the eyes of educated and urbanite Sudanese who were the main supporters of the October uprising. The idea of forming a commission to study the situation was a convenient solution for them. One could even argue that their forces in the government may have favoured the adoption of the idea of a commission as a delaying tactic.

Furthermore, it is known that tribal leaders in Sudan have benefited from their early involvement with government administration by sending their children to schools. Later their children came to occupy prominent positions in government and were represented in the various professions. Through their children tribal leaders were then able to affect the direction of things in the various power circles. To sum up, the tide of liquidation was slowed because of different political factors. Bakheit argued that the idea of a study was in fact an expedient political tactic for all forces:

The conclusion is that all shades of political authority agree with each other in raising liquidation as a slogan. No political force was able to withdraw theoretically from its commitment of the October days that liquidation was the call of the masses. But at the same time no force was able to practice what it preached. No man in authority 
was able to contemplate the rural areas being void of nazirs, shaikhs and chiefs; these were the pillars of authority in a country where authority was so fragmented that it tended to lose effect and gradually die. (Bakheit, 1971, 247)

So the liquidation of native administration which was the subject of so many political speeches, debates and newspaper articles, was effectively shelved until the leftists had their day in court.

\section{The Abolition of Native Administration}

On May 25, 1969 a new regime to power in Sudan as a result of a military coup. It promised a socialist revolution that would create a new social order based on nonexploitative relations. The new gouvernment was backed by the same leftist elements who were active supporters of the liquidation of native administration in the October days.

A month or so after the coup, the abolition of native administration was announced. However, native administration personal of the rank of omda and below were allowed to keep their roles as tax collectors only. The abolition did not apply to the powerful chiefs of tribal groups that livenear Sudan's borders. The most important examples were the Kobé (Zaghawa) and the Masalit of Darfur - living near the Chadian border. Local government officials were left to devise their own method of facing the situation. Since no alternative set of personal was in place in the power hierarchy, they found it all the more difficult to convey governmental regulations to the people. The omda and the village headman were not helpful in this connection since they themselves felt threatened and believed that it was only a matter of time before they would loose their of fices. Furthermore, they had less experience in direct contact with government of ficials. Moreover, the climate was suitable for dissenting tribal elements to be more active, which meant that omdas and headmen became more vulnerable.

The judicial functions of the abolished native administration needed reassignment. The Chief Justice was asked to dissolve native courts and establish benches of magistrates in their places in the areas where it was feasible. The bench of magistrates consists of twelve members or more. It operates according to a rotation system whereby a group of three members sit for three months and each one acts as a president for one month. As Salman has shown in his study of judicial administration and organization in Sudan, the conduct of the Chief Justice over this issue was characterized by inconsistency and ambivalence. Salman argued further that, '... serious legal lacunae characterize the process of surpressing native courts, the establishment of the benches of magistrates, and the regulation of supervisory control over those benchest. (Salman, 1977, 291). The benches of magistrates that were established included younger men who lacked experience and training. This mainly resulted from the regulation that only literate people were allowed to be member of the bench. Also the whole procedure was hastily conducted and so the of ficials did not have time to devise an appropriate selection procedure. It was a chance 
for many dissenting elements to come to power, indeed many of them successfully took advantage of this situation.

The judiciary welcomed the founding of these new organs as the situation gave them the chance to fulfill their dreams of a unified judicial system. The power to establish benches of magistrates was vested solely in the Chief Justice according to section 10 (A) of the Criminal Procedure Code. But the satisfaction of the judiciary was not to last long as problems soon started to appear that were beyond their capacity to handle. The fact that the judiciary were exclusively responsible for the new courts has given rise to three main problems. The first has to do with the provision of financial resources. Previously the Ministry of Local Government had to handle court finances but after the abolition it refused responsibility for managing the resources of the new courts. Secondly, according to the provisions under which the new courts were established, the magistrates were supposed to apply state codes and not customary law. Needless to say the personal of these courts lacked training in state law and the judiciary was not prepared to offer any such training. Thirdly, under state codes criminal cases must be investigated by the police before they are presented to the benches of magistrates for final decisions. Police stations exist only in towns and large rural settlements. For example, in the district of Kutum in northern Darfur there were only nine police stations (many of them undermanned) while there were twenty-five courts. There was simply no way for the limited number of policemen to perform the work required by these courts.

All this resulted in various types of inefficiency, the most important of which are: (a) The number of cases appealed to the resident magistrate's courts increased dramatically. It became difficult for judges to handle the increased volume of work. (b) The rotation system meant that complex cases were delayed for longer periods because bench members kept changing position. Other delays occurred as a result of the reduced number of days on which cases were heard (one or two times a week) and (c) Corruption increased as the supervision of court finances by the judiciary was inadequate.

The inefficiencies fo the benches of magistrates, added to the abolition of native administration, resulted in a lack of security as well as a dilution of the image of government. As the Attorny General noticed in an explanatory note to a proposed 1975 act:

The lack of order meant that people no longer felt secure in their lives and property.

They disposed of their animals for the fear that keeping them may cost them their

lives. This is because the courts no longer apply local custom among them. (Attorney

General's Chambers - my translation).

The setback for local government was more devastating. Councils were not able to collect taxes or implement regulations as efficiently as they used to. The remaining lower native administration personnel were helpless because they had no judicial powers. This meant that field administrators could not utilize legal sanction effectively to get work done although theoretically such avenues were supposed to be available.

The Local Government Act of 1971 which was envisaged as the alternative to native administration failed to fill the gap partially because of the lack of legal instruments. The newly formed people's local councils became forums for debates while their powers 
of execution had been seriously hampered. Local government officials finally started to point to the 'gap'. As a result, a Presidential Act was passed in 1973 that authorized local government officials to establish People's Local Councils Courts. These courts were supposed to deal mainly with the enforcement of local acts, regulation of services and collection of taxes. However, the whole scheme never got of the ground.

It is clear from the above discussion that the liquidation movement succeeded in getting native administration legislated out of existence. However, by no means can it be argued that native administration was ever liquidated in Sudan. During the supression period tribal leaders managed to survive in two ways. Firstly, some of the old administrators managed to reappear on local councils and benches of magistrates or at least get some of their associates working in these institutions. This partially secured the continuity of their social influence. Secondly, where serious security problems arose (e. g. tribal fights) the government had no option but to resort to tribal leaders in order to participate in the reconciliation process. The government has no means to keep law and order in every community around the country so, for reasons of expediency, it often compromises. This proved to be the life line for native administration during the supression period. The fact that some native courts continued to operate during this period was also helpful.

\section{From Native Courts to people's local Courts}

In July 1971 the main ideological supporters of the regime (the communists) were expelled from the government. After an unsucessful coup the regime conducted a massive purge against them. Since the early seventies the abolished parties of the right of centre have joined forces in opposition to the regime. Various destablization tactics have been employed from within the country as well as across the borders from neighbouring countries. The left also joined the opposition forces after their alliance with the regime was over. The second serious attempt to overthrow the government was the abortive coup of September 1975, followed by another in July 1976. To consolidate its position, the regime created its own single party (the only officially recognized party in Sudan to date), the Sudan Socialist Union. It engaged in massive programs to create grassroot organizations in the villages and towns of the country. These organizations include: People's Local Councils, Village Development Committees, Youth Unions, Women's Unions and Parent's Councils. Local SSU chapters are closely associated with these new entities (collectively called Popular Organizations). Indeed, the former has supervisory powers over the latter.

The popular organizations were largely joined by young and dissenting elements who found in them the opportunity to undercut the influence of traditional dignitarias and tribal leaders. However, this did not result in more efficient local administration. In a country like Sudan, field administration are usually interested in two things; order and tax collecting (the latter is the life-line of government machinery). As neither of these two improved, it was only logical that new solutions were sought. The 1973 People's 
Local Councils Courts Act was supposed to improve the situation, but it was never applied.

Another development in the political arena in the first half of the seventies was that the regime started to incline towards the right in terms of ideology. Relations with the Soviet Union stopped as a result of the purge against the communists and the regime started to look to the West. Consequently, the government was no longer sensitive to the participation of tribal elites in the administration. In fact it allowed many of them to run as candidates for local councils and the People's Assembly. Because the opposition was traditionally allied with the tribal elites, one can argue that the government started wooing the latter to alienate the opposition from their constituencies.

The People's Local Courts Act of 1976 came as a result of these developments. ${ }^{6}$ It repealed the Chief's Courts Ordiance of 1931, the Native Courts Ordinance of 1932 and the People's Local Councils Act of 1973. Benches of magistrates were replaced by the newly structured courts (of course it took some time for the replacement process to take place).

The new courts are very similar in form and content to their predecessors, the native courts. They administer customary law. Their jurisdiction does not include cases involving ownership of land or cases involving public officials. The repugnancy provision pertaining to native customs still stands. Each courts has a president and a vicepresident, both of whom are permanently employed and receive improved salaries. The only substantial difference between the new customary courts and their predecessors is that the judiciary now dominate in establishing and supervising the new units (although local government officials are involved in the processes of location and selection of members). It could be said, therefore, that as far as professional interests are concerned the judiciary were able to win the day.

Although it was not a declared policy by the government, the regulations that the Chief Justice has passed pointing to the importance of appointing 'experienced' persons to lead the new courts actually resulted in appointing ex-native administration personnel to these positions. Under the provisions of section 6 (2) of the act members of the local courts are nominated by the resident magistrate in consultation with the administrative of ficer, security officer, president of the People's Local Council and the branch secretary of the SSU. Having witnessed the gap created by the abolition of native courts, it is no wonder that the magistrate, the administrative officer and the security officer prefer dealing with people of power and influence be they ex-native administrators or not. The tribal leaders, it seems, have re-emerged from their enforced hibernation even stronger than before.

The single most important result of the new act is that it paved the way for the reappearance of the old figures of native administration. About $90 \%$ of the courts in the Kutum area now have presidents who used to occupy the same positions in the abolished native courts. Similar patterns have also been observed in other parts of the country.

6 This was amended in another act in 1977 which is practically the same except for substituting the Peoples Local Government Minister with Province Commissioner. 


\section{Concluding Remarks}

It is clear from the above account that the development of customary courts in Sudan is following a circular pattern. This has been largely dictated by political factors in the general sense of the word. As indicated earlier, native courts were the stronger component of native administration. The reintroduction of native courts in the new form of people's local courts may turn out to be a preamble for the reintroduction of the other half of native administration.

Sudan entered a new era of decentralized government in 1980. The regional governments in Darfur and Kordofan are already contemplating the reintroduction of a reformed version of native administration. They argue that it is difficult to keep order in their predominantly rural territories without the help of experienced tribal leaders. The call is now for reform not liquidation. If this tide should continue we may see a reincarnation of the native administration system in Sudan in the not-too-distant future. People's local government may also be restructured to accomodate chiefs, nazirs and shaikhs in one capacity or another.

The development of customary courts in Sudan up to 1976 seemed to be going in the same direction as their counterparts in other African countries that had experienced Indirect Rule. The local courts in Nigeria, Ghana, Tanzania and Zambia are all developing towards a unitary system. In her discussion of the situation in Zambia, Elizabeth Colson reports:

The courts have been placed under the Ministry of Justice, which seeks to bring the customary courts into close conformity with the standards of the legal profession through various training programs for personnel and close supervision of the work of the courts by Local Courts Advisors stationed in the various provinces. (Colson, 1976; 25).

The Judiciary in Sudan, as we have seen, very much supports this trend. One Sudanese legal scholar with whose analysis of the court system I agree to a great extent also falls in this trap. Salman recommends: 'Having in mind the experience of the aforementioned African countries and the indiosyncracies of the Sudan, I believe, as far as those lay tribunals are concerned, that the objective should be a full-time stipendary magistracy. (Salman 1977, 348).

I find it difficult to support a unification policy. In my view, the reform of the legal system should not concern itself with the elimination of pluralism (which could be a healthy sign) but rather maintain the balance between the center and the periphery. The degree to which courts can perform their function of administration of justice depends on their capacity to redistribute power. Access to power is what social control is all about. If the ordinary people had a chance to control the government as much as the government was able to control them, much of the wasted effort in reforming customary courts in Sudan would have been saved. This unhappy story is a case in point for the following observation by Nader and Serber:

While under colonialism law was used to administer and control, the motivation of the 
new states is more elaborate. The leadership in many of these new states deeply believes that national success, meaning economic development, depends on creating a homogeneous people, and that the best way to do this is by means of law, usually law imported from the West. These elites seem to be functioning as if the seeds of progress and modernity are somehow linked to the importation of a legal system or code from a more developed country. Often a country where they had received their formal education. Furthermore, in these new nations new loci of power are developing and consolidating, and the law is often used as a means to consolidate power positions. (Nader \& Serber, 1976, 278).

It seems that our politicians as well as our educated professionals see the development of our legal system in terms of the subjugation of our dispute management institutions to a transplanted Western legal system. For them, legal pluralism (or cultural pluralism for that matter) is a pathology and an obstacle to the process of nation building. This is where our greatest problems lie. The most important lesson to be drawn from the Sudanese experience with customary law courts is that reform of legal institutions cannot succeed without a comprehensive plan that takes into consideration the social structure of the country concerned. In order to do this, the social context of legal institutions must be investigated first. For law cannot be considered an autonomous field in the process of social change. I hope I have been able to demonstrate that here.

\section{Postscript}

In September 1983 a Presidential Decree was passed which declared Sharin to be the main source of law in Sudan. Since then every few weeks a new law is passed which repeals an existing law that does not conform with the requirements of Sharia.

The country is clearly undergoing a legal revolution comparable only, in modern history, to the cases of Turkey and the Soviet Union in the 1920s. It is too early for this change to be studied and evaluated on a scientific basis because the process is not finished yet. However, two areas of influence on customary law courts could already be identified. Firstly, it is common knowledge that the customs of many ethnic groups in Sudan are not in conformity with the rules of Sharia. The new legal system will probably not tolerate such contradiction. Secondly benches of magistrates have been legislated back to replace peoples local courts. It is not clear yet wether the replacement is going to be total or partial.

Regarding the connection with native administration, it is important to notice that the regional governments of Kordofan and Darfur managed to pass legislations which give omdas the powers of a third class magistrate. Administrative powers have also been restituted to tribal leaders (of various ranks) in the tow regions. 


\section{References}

Bakheit, J. M. A. 1971. 'Native Administration in the Sudan and its Significance to 'Africas in $Y$. Hassan (ed.) Sudan in Africa, pp. Khartoum: Khartoum University Press.

Colson, E., 1976. From Chiefs' Courts to Local Courts, in M. T. Arnoff(ed.), Freedom and Constraint, pp. 15-29. Amsterdam: Van Gorcum.

Nader, L. and Serber, D., 1976. Law and Distribution of Power, in L. A. Coser and $O$. N. Larson (eds.), The Uses of Controversy in Sociology, pp. 273-291, New York: Free Press.

Salman, S. M. A., 1977. Judical Administration and Organization in The Sudan: Impact of Political and Socio-Economic Factors. (Unpublished J.S.D. thesis) Yale Law School.

Shapiro, M., 1980. Courts, a Comparative Perspective and Political Analysis, Chicago: University of Chicago Press. 


\title{
ABSTRACTS
}

\section{Law Reform in Africa: A Comparative Study of the Tanzanian and Kenyan Experiments}

\author{
By D. R. Salter and J. B. Ojwang
}

This article begins with an outline of the general philosophical issues affecting law reform and seeks to identify those issues which have a particular relevance to African countries. Further it reveals that the general constraints on law reform are present in Tanzania and Kenya and in particular, the need to balance the desire for social change as a goal of national development with the necessity to ensure that any change is so ordered as to maintain a stability within society which is sustained by the legal process.

In this context, the article examines the provisions of two recent statutes, The Law Reform Commission of Tanzania Act (1980) and The Law Reform Commission Act (1982) of Kenya, which introduced in the respective countries law reform bodies charged with the duty of promoting law reform. Particular attention is given to a comparative analysis of the structure, composition and functions of these bodies.

The overall, and, perhaps, surprising conclusion reached (bearing in mind the disparity between the the countries declared political standpoints) is that the two schemes of law reform enjoy many common characteristics not least of which is the prominance of the Government machine in the conduct of law reform.

\section{"From Native Courts to People's Local Courts: The Politics of Judicial Administration in Sudan«}

\section{By Musa Adam Abdul-Jalil}

The paper traces the development of native courts in Sudan since the turn of this century to the present time and attempts to explain the various reform measures (introduced by different governments) in terms of the political interests of those in power. Introduced by the British as a part of the policy of "Indirect Rule", native courts have remained until now the agents of the central governments for controlling rural populations.

The last decade has witnessed three reform attempts, all of which have failed to produce satisfactory results as far as the rural people are concerned. A 1973 act abolished the native courts together with the native administration system and instituted people's courts and people's councils instead. This was an indication of the socialist tendencies of the government at that time. A second reform in 1976 made minor adjustments to deal with 
problems arising from the 1973 law. But then a 1977 act facilitated the comeback of many traditional leaders to the newly reformed people's local courts. Again, this concided with the changing political color of the regime. Therefore, their pattern of development has become circular in nature.

The writer argues that there is a correlation between the various attempts for reforming customary law courts (or courts in general for that matter) and the political interests of those in power. He concludes that the examination of the history of local courts in Sudan not only reveals the nature of political relations between the center and the periphery but also tells us why each political regime wants to structure these relations differently.

Finally the writer suggests that the call for a unitary system is premature under conditions of cultural diversity that prevail in the country. If the legal system is to be efficient it must be grounded in the social system.

\section{Cultural and Social Identities in Africa: Chieftaincy and Political Change in Ghana}

\section{By Kwame Poku Annor}

The position of traditional chiefs in colonial and post-independence Ghana has been the subject of various enactments designed to regulate the functions of this office in the context of overall state administration.

Contrary to widely held expectations chieftaincy did not wither away in the process of independence and modernisation. The present factual situation of chiefs and their work is, however, not well explored. This article identifies some of the areas requiring detailed, systematic study and reports on research initiated in Ghana in this field.

\section{Conflict and Consensus in South African Natural Law Thinking}

By $A J G M$ Sanders

In South African society various currents of natural law thinking are discernible. Whereas to the European mind the dignity of man is determined traditionally by his rights, and society being rights-conscious is one of conflict, according to traditional African, Islamic, and Hindu thinking, man's dignity is related to his duties, and society is a consensus society. Practice, however, points towards a middle course, witness the 1955 Freedom Charter and the policy of consociationalism. It would, however be naive to believe that common standards will be arrived at easily. More social strife seems inevitable. In the long-term process of shaping a new order for South Africa comparative natural law studies, adequately backed by sociological research, could play a vital role. 